\title{
ВИЗНАЧЕННЯ ЯКІСНОГО СКЛАДУ ТА КІЛЬКІСНОГО ВМІСТУ ВУГЛЕВОДІВ У TPABI ПРЕДСТАВНИКІВ РОДИНИ LAMIACEAE JUSS
}

\author{
(c) М. І. Шанайда \\ Тернопільський державний медичний університет імені І. Я. Горбачевського
}

\begin{abstract}
Резюме: проведено порівняльне вивчення вуглеводів (полісахаридів та цукрів) у траві 4 видів родини Lamiaceae: Ocimum americanum L., Lophanthus anisatus Adans., Monarda fistulosa L. та Satureja hortensis L. Визначено загальний вміст полісахаридів, а також здійснено їх фракційне виділення та визначення. Найвищий загальний вміст полісахаридів та їх фрракцій характерний для трави Lophanthus anisatus. Переважаючими фрракціями полісахаридного комплексу трави усіх досліджуваних видів $€$ водорозчинні полісахариди. Методом тонкошарової хроматографрії вивчено мономерний склад полісахаридних фрракцій. Вперше вивчено вміст вільних цукрів у траві досліджуваних видів методом високоефективної газорідинної хромато-мас-спектрометрії. Найбільш різноманітний мономерний склад цукрів виявлено у траві Monarda fistulosa.
\end{abstract}

Ключові слова: вуглеводи, Lamiaceae, Ocimum americanum, Lophanthus anisatus, Monarda fistulosa, Satureja hortensis.

Вступ. Аналіз вуглеводів (моно-, оліго- і полісахаридів) $€$ одним із актуальних питань сучасної фрітохімії [6]. Вуглеводи складають основну масу рослинного організму та є важливим класом природних сполук з різноманітним спектром біологічної дії на організм людини. Для рослинних полісахаридів, які раніше вважали інертними речовинами, на сьогодні вставлено широкий спектр біологічної активності: протизапальну, репаративну, гіполіпідемічну, протипухлинну, імуномодулюючу та пом'якшувальну дію [2, 4]. Тому актуальним завданням фрармацевтичної науки є пошук нових джерел, визначення фрармакологічної дії та розширення спектра практичного застосування рослинних вуглеводів [1, 2, 5, 7, 10]. Дослідження якісного складу та кількісного вмісту вуглеводів у траві представників родини Lamiaceae Juss. проводили вибірково [5], оскільки серед сполук первинного синтезу значно більше уваги приділяють аналізу вітамінів, органічних кислот тощо [12].

Мета наших досліджень - порівняльне вивчення вмісту вуглеводів у траві 4 представників родини Lamiaceae: Ocimum americanum L., Lophanthus anisatus Adans., Monarda fistulosa L та Satureja hortensis L. Сировину для досліджень - надземну частину рослин, вирощених в умовах Західного Поділля, - заготовляли у період цвітіння.

Методи дослідження. Кількісне визначення загального вмісту полісахаридів проводили згідно 3 ДФУ 1.3 [3] гравіметричним методом. Для визначення фрракцій полісахаридів висушену сировину здрібнювали до порошку (сито 750) та знежирювали хлороформом в апараті Сокслета до знебарвлення розчинника, після чого 70 \% спиртом Р екстрагували спирторозчинні сполуки [8]. Далі із висушеного шроту сировини виділяли фрракції полісахаридів: водою вилучали водорозчинні полісахариди (ВРПС), після чого сумішшю 0,5 \% розчинів кислоти оксалатної та амонію оксалату - пектинові речовини (ПР), далі $10 \%$ розчином натрію гідроксиду - геміцелюлозу А (ГЦ А) та при наступному додаванні кислоти льодяної оцтової - геміцелюлозу Б (ГЦ Б). Утворені осади відфільтровували, промивали органічними розчинниками та висушували. Кількісний вміст кожної фрракції полісахаридів визначали гравіметричним методом.

Мономерний склад вуглеводів трави досліджуваних рослин визначали методом тонкошарової хроматографії (ТШX) гідролізатів отриманих фрракцій, а також високоефективної рідинної хроматомас-спектрометрії (визначали вміст вільних цукрів) [6].

Для вивчення моносахаридного складу методом ТШХ використовували попередній кислотний гідроліз полісахаридних фрракцій за допомогою $10 \%$ розчину кислоти сульфатної протягом 5-6 год. Отриманий фрільтрат нейтралізували карбонатом барію за універсальним індикатором і концентрували. Як стандартні зразки моносахаридів використовували арабінозу, галактозу, глюкозу, ксилолу, рамнозу та фрруктозу (концентрація усіх розчинів становила 1 мг/мл). Далі пластинку виймали та висушували на повітрі, після чого обробляли розчином анілін-срталату і витримували в сушильній шафі протягом 5 хв при $105^{\circ} \mathrm{C}$. Моносахариди проявлялись у вигляді червонокоричневих плям.

ISSN 2312-0967. Pharmaceutical review. 2015. № 4 
Фітохімічні дослідження

Phytochemical researches

Подальше дослідження цукрів здійснювали методом високоефективної рідинної хромато-масспектрометрії, який базувався на екстракції вільних моносахаридів та отриманні ацетатів їх альдонітрильних похідних з подальшим аналізом. Хроматографрічне розділення здійснювали на хроматографрі Agilent technologies 6890N/5973 (США). Колонка капілярна HР-5ms $(30 \mathrm{~m} \times 0,25 \mathrm{~mm} \times 0,25 \mathrm{mkm})$. Підготовка проб для аналізу полягала в тому, що сировину перетирали до порошкоподібного стану в скляній ступці. Наважку масою 500 мг поміщали в круглодонну колбу, додавали розчин 80 \% етилового спирту з внутрішнім стандартом із розрахунку 500 мкг на пробу. Екстракцію вільних моносахаридів проводили на водяній бані при $100^{\circ} \mathrm{C}$ з використанням зворотного холодильника впродовж 2 год.

Для отримання альдонітрильних похідних моносахаридів відбирали 2 мл екстракту, упарювали досуха на роторному випаровувачі та додавали 0,3 мл дериватизуючого реактиву (32мг/мл гідроксиламіну солянокислого в суміші піридин/метанол (4:10)). Розчинений екстракт витримували впродовж 25 хв при температурі $75^{\circ} \mathrm{C}$. Для ацетилювання альдонітрильних похідних моносахаридів додавали 1 мл оцтового ангідриду та витримували впродовж 15 хв при $75^{\circ} \mathrm{C}$. До реакційної суміші додавали 2 мл дихлоретану, надлишок дериватизаційних реагентів видаляли подвійною екстракцією $1 \mathrm{~N}$ розчином соляної кислоти та води. Дихлоретановий шар висушували досуха та розчиняли в 300 мкл суміші гептан/етилацетат $(1: 1 \mathrm{v} / \mathrm{v})$.

Ідентифікацію проводили за часом утримання стандартних зразків цукрів та 3 використанням бібліотеки мас-спектрів NIST 02. Кількісний аналіз проводили шляхом додавання розчину внутрішнього стандарту в досліджувані проби. Як внутрішній стандарт використовували розчин сорбітолу.

Вміст моносахаридів (Х, в мг на 1 кг сировини) розраховували за фрормулою:

$$
X=\frac{\mathrm{Sx} \times \mathrm{MECT} \times 1000}{\operatorname{SBCT} \times \mathrm{TI}},
$$

де Sx - площа піку досліджуваного моносахариду чи дисахариду;

Мвст - маса внутрішнього стандарту на пробу;

Sвст - площа піку внутрішнього стандарту;

m - наважка препарату.

Результати й обговорення. На основі проведених досліджень було визначено загальний вміст полісахаридів та їх окремих фрракцій у траві досліджуваних видів родини Lamiaceae (табл. 1).

Як видно 3 таблиці 1, найбільший загальний вміст полісахаридів виявлений у траві Lophanthus anisatus. Переважаючими фракціями полісахаридного комплексу досліджуваних видів $€$ ВРПС. Дещо меншим $€$ вміст ПР і ГЦ Б, а найменшим - ГЦ А. Серед досліджуваних видів Lophanthus anisatus накопичує найвищий вміст ВРПС, ПР та ГЦ А; Satureja hortensis ГЦ Б.

Результати вивчення моносахаридного складу полісахаридних фрракцій, здійсненого методом ТШХ, наведено в таблиці 2. Як видно з таблиці 2, найбільш різноманітний склад моносахаридів у траві усіх досліджуваних видів виявлено у гідролізаті фрракції ВРПС. Практично в усіх фрракціях досліджуваних видів ідентифріковано глюкозу; інші мономери полісахаридів виявлялись рідше.

Хромато-мас-спектрометричним методом нами вперше вивчено вміст вільних цукрів у траві досліджуваних представників родини Lamiaceae (табл. 3). Як видно 3 таблиці 3, у траві Ocimum americanum виявлено 24 цукри, з яких 7 ідентифіковано; в траві Lophanthus anisatus виявлено 13 (з них 5 ідентифріковано), в траві Monarda fistulosa 18 (з них 7 ідентифріковано), в траві Satureja hortensis 25 (3 них 6 ідентифріковано).

Таким чином, найрізноманітніший мономерний склад цукрів виявлено у траві Monarda fistulosa. Фруктоза є домінуючим компонентом трави Ocimum americanum, Lophanthus anisatus та Monarda fistulosa, глюкоза і сахароза - Satureja hortensis (табл. 3). Загалом якісний склад цукрів трави досліджуваних видів подібний. Відмінності полягають здебільшого в кількісному вмісті компонентів.

Таблиця 1. Кількісний вміст окремих фрракцій полісахаридів у надземній частині представників родини Lamiaceae, \%

\begin{tabular}{|c|c|c|c|c|}
\hline \multirow{2}{*}{$\begin{array}{c}\text { Вміст } \\
\text { полісахаридів, \% }\end{array}$} & $\begin{array}{c}\text { Трава } \\
\text { Ocimum americanum }\end{array}$ & $\begin{array}{c}\text { Трава } \\
\text { Lophanthus anisatus }\end{array}$ & $\begin{array}{c}\text { Трава } \\
\text { Monarda fistulosa }\end{array}$ & $\begin{array}{c}\text { Tpaва } \\
\text { Satureja hortensis }\end{array}$ \\
\cline { 2 - 5 } & $2,72 \pm 0,01$ & $4,46 \pm 0,03$ & $2,48 \pm 0,02$ & $4,20 \pm 0,02$ \\
\hline \multicolumn{5}{|c|}{ Вміст фрракціонованих полісахаридів, \% } \\
\hline ВРПС & $12,06 \pm 0,01$ & $14,08 \pm 0,05$ & $9,93 \pm 0,04$ & $13,14 \pm 0,02$ \\
\hline ПР & $7,13 \pm 0,03$ & $9,03 \pm 0,04$ & $5,43 \pm 0,04$ & $7,53 \pm 0,03$ \\
\hline ГЦ А & $0,96 \pm 0,01$ & $1,29 \pm 0,01$ & $1,02 \pm 0,01$ & $0,93 \pm 0,01$ \\
\hline ГЦ Б & $5,29 \pm 0,08$ & $4,98 \pm 0,06$ & $3,76 \pm 0,02$ & $5,41 \pm 0,01$ \\
\hline
\end{tabular}

ISSN 2312-0967. Фармацевтичний часопис. 2015. № 4 
Фітохімічні дослідження Phytochemical researches

Таблиця 2. Результати вивчення мономерного складу полісахаридних фрракцій трави представників родини Lamiaceae методом ТШХ

\begin{tabular}{|c|c|c|c|c|c|c|c|}
\hline $\begin{array}{c}\text { Об'єкт } \\
\text { дослідження }\end{array}$ & $\begin{array}{c}\text { Гідролізат } \\
\text { фрракцій }\end{array}$ & Арабіноза & Галактоза & Глюкоза & Ксилоза & Рамноза & Фруктоза \\
\hline \multirow{4}{*}{$\begin{array}{l}\text { Трава } \\
\text { Ocimum } \\
\text { americanum }\end{array}$} & ВРПС & + & + & + & + & + & + \\
\hline & $\Pi \mathrm{P}$ & - & + & + & + & - & + \\
\hline & ГЦА & + & - & + & - & - & - \\
\hline & ГЦ Б & + & - & - & - & - & - \\
\hline \multirow{4}{*}{$\begin{array}{l}\text { Трава } \\
\text { Lophanthus } \\
\text { anisatus }\end{array}$} & ВРПС & + & + & + & + & + & + \\
\hline & $\Pi \mathrm{P}$ & - & + & + & + & - & + \\
\hline & ГЦА & + & - & + & - & - & - \\
\hline & ГЦ Б & + & - & + & - & - & - \\
\hline \multirow{4}{*}{$\begin{array}{l}\text { Трава } \\
\text { Monarda } \\
\text { fistulosa }\end{array}$} & ВРПС & + & + & + & + & + & + \\
\hline & $\Pi \mathrm{P}$ & - & + & - & - & + & + \\
\hline & ГЦ А & - & - & + & - & - & - \\
\hline & ГЦ Б & - & - & + & - & - & - \\
\hline \multirow{4}{*}{$\begin{array}{l}\text { Tрава } \\
\text { Satureja } \\
\text { hortensis }\end{array}$} & ВРПС & + & + & + & + & + & + \\
\hline & $\Pi \mathrm{P}$ & + & - & + & + & + & + \\
\hline & ГЦА & - & - & + & - & - & - \\
\hline & ГЦ Б & + & - & + & - & - & - \\
\hline
\end{tabular}

Таблиця 3. Результати ідентифікації та визначення вмісту вільних цукрів у траві представників родини Lamiaceae хромато-мас-спектрометричним методом (мг/кг)

\begin{tabular}{|c|c|c|c|c|}
\hline Назва вуглеводу & $\begin{array}{c}\text { Трава } \\
\text { Ocimum americanum }\end{array}$ & $\begin{array}{c}\text { Tрава } \\
\text { Lophanthus anisatus }\end{array}$ & $\begin{array}{c}\text { Tpава } \\
\text { Monarda fistulosa }\end{array}$ & $\begin{array}{c}\text { Tpaвa } \\
\text { Satureja hortensis }\end{array}$ \\
\hline Рамноза & - & 0,22 & 0,08 & 3,84 \\
\hline Арабіноза & 0,38 & 0,30 & 0,07 & 7,44 \\
\hline Фукоза & 0,25 & - & - & - \\
\hline Маноза & 15,39 & - & 0,51 & 10,21 \\
\hline Глюкоза & 17,57 & 40,63 & 3,78 & 93,89 \\
\hline Галактоза & 4,85 & 3,48 & 0,50 & - \\
\hline Фруктоза & 36,08 & 57,61 & 6,27 & 86,83 \\
\hline Сахароза & 18,01 & - & 5,20 & 97,40 \\
\hline
\end{tabular}

Висновки. 1. Вперше здійснено порівняльне вивчення вмісту полісахаридів та цукрів у траві 4 видів родини родини Lamiaceae: Ocimum americanum, Lophanthus anisatus, Monarda fistulosa та Satureja hortensis.

2. Визначено загальний вміст полісахаридів та їх фрракцій. Найбільший загальний вміст полісахаридів виявлено у траві Lophanthus anisatus $(4,46 \pm 0,03)$, найменший - у траві Monarda fistulosa $(2,48 \pm 0,02)$.

\section{Список літератури}

1. Амінокислотний та цукровий склад спиртового екстракту з листя шавлії лікарської / [О. М. Кошовий, Г. П. Зайцев, А. М. Ковальова, А. М. Комісаренко] // Вісник фрармації. - 2011. - № 1 (65). - С. 49-52.

2. Бурцева О. В. Вивчення полісахаридного складу
3. Методами тонкошарової хроматографії та високоефективної рідинної хромато-мас-спектрометрії у траві досліджуваних видів рослин виявлено від 5 до 7 цукрів. Найрізноманітнішим складом цукрів характеризується трава Monarda fistulosa (встановлено наявність та кількісний вміст рамнози, арабінози, фукози, манози, глюкози, галактози, фрруктози та сахарози).

Avena sativa L. / O. В. Бурцева, І. І. Тернинко // Вісник фрармації. - 2010. - 2(62). - С. 46-48.

3. Державна Фармакопея України. - 1-е вид. Доповнення 3. - Харків : ДП «Науково-експертний фармакопейний центр», 2009. - 280 с.

ISSN 2312-0967. Pharmaceutical review. 2015. № 4 
4. Колісник Ю. С. Полісахариди та органічні кислоти трави грициків звичайних / Ю. С. Колісник, В. С. Кисличенко, В. Ю. Кузнецова // Фітотерапія. Часопис. - 2013. - № 1. - С. 55-58.

5. Марчишин С. М. Полісахаридний склад трави Dracocephalum moldavica L. та Monarda fistulosa L. / C. М. Марчишин, M. I. Шанайда // Матеріали II Міжнародної наукової коноеренції «Лікарські рослини: традиції та перспективи досліджень» (Березоточа, 4-5 червня 2014 р.). - Лубни, 2014. - С. 174-176.

6. Оленников Н. Д. Методика количественного определения группового состава углеводного комплекса растительных объектов / Д. Н. Оленников, Л. М. Танхаева // Химия раст. сырья. - 2006. - № 4. - С. 29-33.

7. Полисахаридный и аминокислотный состав наиболее распространенных видов лабазника / М. Ю. Круглова, Д. С. Круглов, М. А. Ханина, Н. С. Фурса // Медицина и образование Сибири. - 2011. - № 5.С. 35-38.

8. Цуркан О. О. Фітохімічне дослідження вуглеводних компонентів шовковиці білої та чорної / О. О. Цуркан, Т. В. Ковальчук, О. В. Гергель // Фітотерапія. Часопис. 2010. - № 4. - C. 72-75.

9. Analysis of the monosaccharide composition of purified polysaccharides in Ganoderma atrum by capillary gas chromatography / Y. Chen, M. Xie, Y. Wang [et al.] // Phytochem. Anal. - 2009. - 20(6). - P. 503-510.

10. Isolation of a previously unidentified polysaccharide (MAR-10) from Hyssop officinalis that exhibits strong activity against Human Immunodeficiency Virus Type 1 / S. Gollapudi, H. Sharma, S. Aggarwal [et al.] // Biochem. Res. Commun. - 1995. - Vol. 210(1). - P. 145-151.

11. Li X.L. Evaluation of the antioxidant effects of polysaccharides extracted from Lycium barbarum / X. L. Li, A. G. Zhou // Med. Chem. Res. - 2007. - Vol. 15. - P. 471482.

12. Preliminary phytochemical screening of members of Lamiaceae Family / R. Vaishali, P. Ramanath, P. Kedilaya, S. Hegde // Int. J. Pharm. Sci. Rev. Res. - 2013. - Vol. 21(1). - P. 131-137.

\title{
ОПРЕДЕЛЕНИЕ КАЧЕСТВЕННОГО СОСТАВА И КОЛИЧЕСТВЕННОГО СОДЕРЖАНИЯ УГЛЕВОДОВ В TPAВЕ ПРЕДСТАВИТЕЛЕЙ СЕМЕЙСТВА LAMIACEAE JUSS.
}

\section{М. И. Шанайда}

Тернопольский государственный медицинский университет имени И. Я. Горбачевского

Резюме: проведено сравнительное исследование углеводов (полисахаридов и сахаров) в траве 4 представителей семейства Lamiaceae: Ocimum americanum L., Lophanthus anisatus Adans., Monarda fistulosa L. $и$ Satureja hortensis $L$. Определено общее содержание полисахаридов, а также выполнено их фрракционное выделение и определение. Установлено, что наивысшее общее содержание полисахаридов характерно для травы Lophanthus anisatus. Преобладающими фрракциями полисахаридного комплекса травы всех исследуемых видов являются водорастворимые полисахариды. Методом тонкослойной хроматографии изучен мономерный состав полисахаридных фрракций. Методом высокоэффрективной жидкостной хромато-масс-спектрометрии установлено содержание свободных сахаров в траве изучаемых видов. Наиболее разнообразный мономерный состав сахаров выявлен в траве Monarda fistulosa.

Ключевые слова: углеводы, Lamiaceae, Ocimum americanum, Lophanthus anisatus, Monarda fistulosa, Satureja hortensis.

\section{DETERMINATION OF QUALITATIVE COMPOSITION AND QUANTITATIVE CONTENT OF CARBOHYDRATES IN THE HERB OF THE SPECIES BELONGING TO LAMIACEAE FAMILY}

\author{
M. I. Shanayda \\ Ternopil State Medical University by I. Ya. Horbachevsky
}

Summary: the comparative research of polysaccharides and sugars in the herb of 4 species belonging to Lamiaceae Family (Ocimum americanum L., Lophanthus anisatus Adans., Monarda fistulosa L. and Satureja hortensis L.) was carried out. It was determined the total content of polysaccharides and their fractions. Lophanthus anisatus has the highest total content of polysaccharides. Water-soluble polysaccharides are the dominant fractions of investigated species. The monomer composition of polysaccharide fractions was investigated by thin layer chromatography method. The content of free sugars was studied by HPLC-MS mathod. The most diverse monomer composition of sugars it was determined in herb of Monarda fistulosa.

Key words: carbohydrates, Lamiaceae, Ocimum americanum, Lophanthus anisatus, Monarda fistulosa, Satureja hortensis.

Отримано 20.08.2015

ISSN 2312-0967. Фармацевтичний часопис. 2015. № 4 